\title{
Determination of Contact Angle Values of Heat-Treated Spruce (Picea abies) Wood with Image Analysis Program
}

\author{
Semsettin Kilincarslan* and Yasemin Simsek \\ Department of Civil Engineering, Isparta, Turkey \\ *Corresponding author: Şemsettin Kilinçarslan, Department of Civil Engineering, Isparta, Turkey
}

\begin{tabular}{|c|c|}
\hline ARTICLE INFO & ABSTRACT \\
\hline Received: 幽 May 30, 2019 & \multirow{7}{*}{$\begin{array}{l}\text { Heat treatment of wood material increases the dimensional stability and prevents } \\
\text { cracks on the wood surface formed by rain and harmful rays. In this study, the effect } \\
\text { of heat treatment application on the contact angle values of heat-treated Spruce (Picea } \\
\text { abies) wood was investigated. For this purpose, drop }(5 \mu \text { ) was dropped onto the surface } \\
\text { with the help of a syringe and images were taken with the digital camera. The images } \\
\text { were transferred to the computer and contact angle values were determined by using } \\
\text { image analysis program. Surface contact angle values of the spruce wood were increased } \\
\text { with the application of heat treatment. Therefore, it has been determined that the sur- } \\
\text { face wettability properties decrease with heat treating application. }\end{array}$} \\
\hline Published: 幽 June 06, 2019 & \\
\hline Kilincarslan, & \\
\hline Yasemin Simsek. Determination of & \\
\hline Contact Angle Values of Heat-Treated & \\
\hline pruce (Picea abies) Wood with Image & \\
\hline & \\
\hline
\end{tabular}

\section{Introduction}

One of the most important problems of wood materials is the dimensional change and decay with environmental impact [14]. Chemical methods used in the wood material modification, are easily applied, and the wood protects against deterioration and decay of material [5]. Heat treatment; it is an alternative modification method to the use of chemicals in order to increase the dimensional stabilization of the wood material and to protect it against tree pests [6]. The aim of this study is to determine the surface contact angle values of heat treated (HT) and unheat treated (UHT) spruce wood and to evaluate about the dynamic wetting properties of this material.

\section{Material and Methods}

In this study were studied on spruce (Picea abies) wood. The timber (heat treated and unheat treated) used in the study was obtained from the forest products factory. Firstly, contact angles were determined by using contact angle method to determine surface wettability properties on spruce wood materials. For this purpose, 30 pieces samples have been cut (spruce; 15 heat treated materials, 15 unheat treated materials) in $20 \times 20 \times 30$ $\mathrm{mm}$ dimensions. The samples were stored until they reached equilibrium humidity in air conditioning cabinet [7-10]. After the water drop ( $5 \mu \mathrm{l}$ ) was dropped onto the surface, images were taken every 5 seconds during 30 seconds. The images were transferred to the image analysis program "image $j$ " and the contact angle values of the drops were determined by this program.

\section{Results and Discussion}

The tangential ( $\mathrm{T}$ ) and radial (R) direction contact angle values of the spruce (heat treated-unheat treated) test samples are given in Table 1 and Figure 1. At the end of the 30th seconds (lowest) contact angle of the heat-treated spruce samples is $77.38^{\circ}$ in the tangential direction and $72.74^{\circ}$ in the radial direction. At the end of the $30^{\text {th }}$ seconds (lowest) contact angle of the unheat treated spruce samples is $30,87^{\circ}$ in the tangential direction and $27,37^{\circ}$ in the radial direction. Kocaefe et al. (2008) determined that the surface contact angle of the wood material increases with the heat treatment application. 
Table 1: Results of contact angle values on spruce wood surface.

\begin{tabular}{|c|c|c|c|c|c|c|c|}
\hline Treatment/Time (sec.) & $\mathbf{0}$ & $\mathbf{5}$ & $\mathbf{1 0}$ & $\mathbf{1 5}$ & $\mathbf{2 0}$ & $\mathbf{2 5}$ & $\mathbf{3 0}$ \\
\hline UHT-R & 80,37 & 71,79 & 60,14 & 50,85 & 40,36 & 33,96 & 27,37 \\
\hline UHT-T & 81,37 & 72,77 & 63,43 & 52,40 & 44,62 & 35,99 & 30,87 \\
\hline HT-R & 129,65 & 126,74 & 118,36 & 108,48 & 92,47 & 83,58 & 72,74 \\
\hline HT-T & 130,37 & 127,82 & 122,16 & 117,66 & 99,27 & 86,98 & 77,38 \\
\hline
\end{tabular}

Note:

*UHT: Unheat-treated HT: Heat-treated R: Radial section, T: Tangential section.

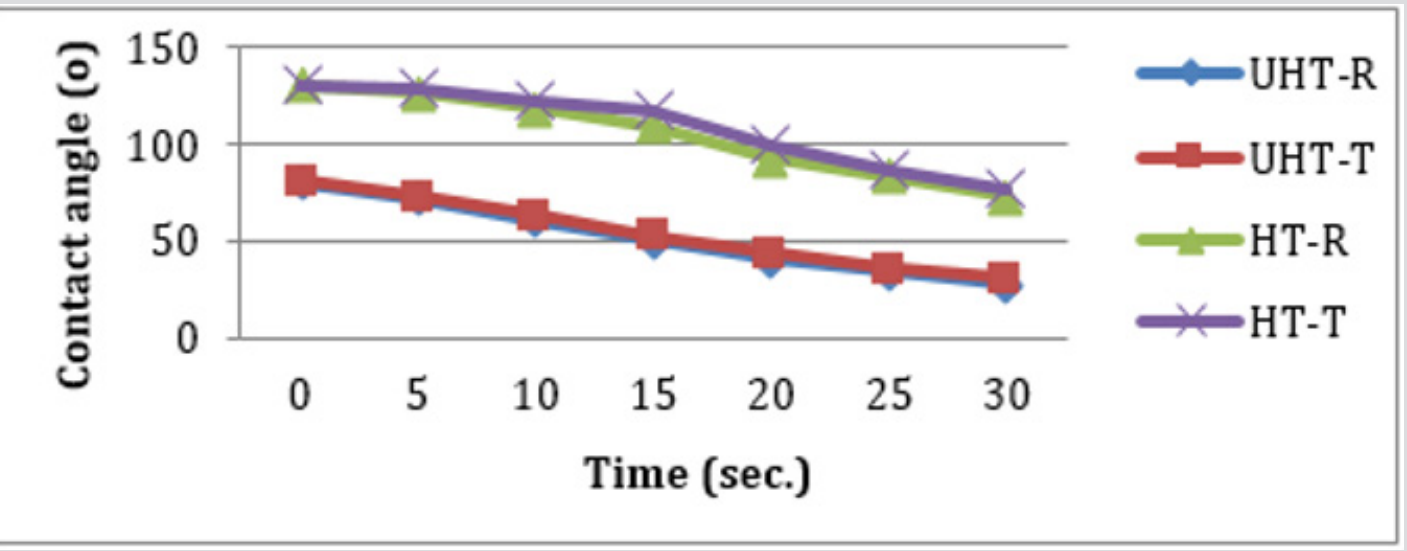

Figure 1: Contact angle values of Spruce samples throughout 30 seconds.

\section{Conclusion}

It was determined that the wettability properties of spruce wood decreased by the application of heat treatment. In line with this result, the use of ThermoWood treated wood materials outdoors in damp environments will be more favorable compared to untreated wood material. "Image J" program could use to determine the dynamic wetting properties of the wood surface.

\section{References}

1. Aydemir D, Gündüz G (2009) The Effect of Heat Treatment on Physical, Chemical, Mechanical and Biological Properties of Wood. Journal of Bartın Faculty of Forestry 11: 71-81.

2. Berkel AA (1972) Wood Material Technology: Wood Material Protection and Impregnation Technique. Istanbul University Faculty of Forestry Publications, Istanbul.

3. Enjily V, Jones D (2006) The Potential for Modified Materials in the Panel Products Industry. in: Wood Resources and Panel Properties, COST Action E44/E49. Valencia, Spain.

\section{ISSN: 2574-1241}

DOI: 10.26717/BJSTR.2019.18.003183

Semsettin Kilincarslan. Biomed J Sci \& Tech Res

CC (P) This work is licensed under Creative

Submission Link: https://biomedres.us/submit-manuscript.php
4. Esteves B, Pereira H (2008) Wood modification by heat treatment: A review. BioResources 4(1): 370-404.

5. Hakkou M, Petrissans M, Zoulalian A, Gerardin P (2005) Investigation of wood wettability changes during heat treatment on the basis of chemical analysis. Polymer degradation and stability 89(1): 1-5.

6. Hill CA (2007) Wood modification: chemical, thermal and other processes (Vol. 5). John Wiley Sons.

7. Kamdem DP, Pizzi A, Jermannaud A (2002) Durability of heat-treated wood. Holz als Roh-und Werkstoff 60(1): 1-6.

8. Kocaefe D, Poncsak S, Doré G, Younsi R (2008) Effect of heat treatment on the wettability of white ash and soft maple by water. Holz als roh-und werkstoff 66(5): 355-361.

9. Tomak ED, Ustaomer D, Yildiz S, Pesman E (2014) Changes in Surface and Mechanical Properties of Heat-Treated Wood During Natural Weathering. Measurement 53: 30-39.

10. Wikberg H (2004) Advanced Solid State Nmr Spectroscopic Techniques in the Study of Thermally Modified Wood. University of Helsinki, Department of Chemistry, Laboratory of Polymer Chemistry, Helsinki, Finland.

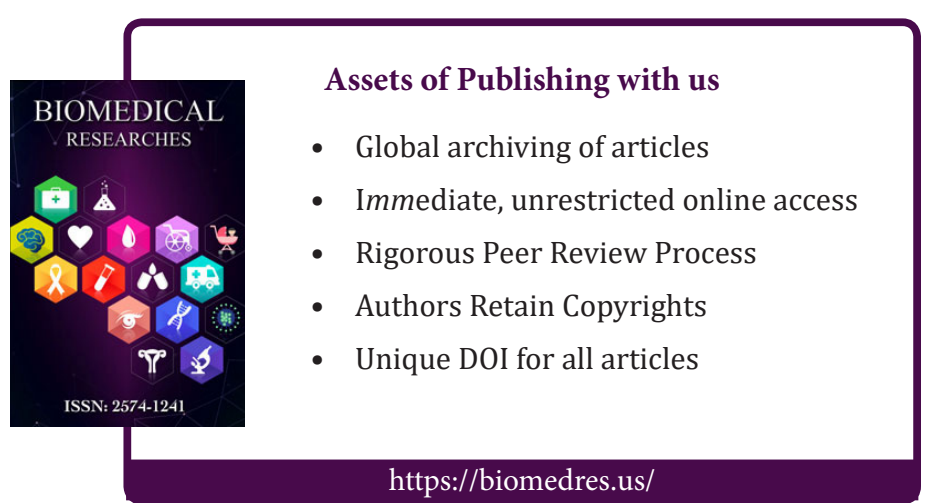

